\title{
РЕЦЕНЗIÏ
}

DOI https://doi.org/10.32837/pyuv.v0i2(27).220

\author{
O. I. Нікітенко \\ доктор юридичних наук, професор, \\ заслужений юрист України, \\ професор кафедри публічно-правових дисииплін \\ Білоцерківського національного аграрного університету
}

\section{РЕЦЕНЗІЯ НА МОНОГРАФІЮ І. С. ПИРОГИ «МЕХАНІЗМ ПОДАТКОВОГО СТИМУЛЮВАННЯ СОЦІАЛЬНО-ЕКОНОМІЧНОГО РОЗВИТКУ УКРАЇНИ" ${ }^{1}$}

Виклики сучасності, зокрема російська агресія на сході України, спровокували фінансово-економічну кризу, подолання якої вимагає уточнення ролі та місця податків у державній економічній політиці. Світова практика оподаткування свідчить про те, що більшість країн у системі заходів антикризового регулювання економіки тією чи іншою мірою використовують оподаткування не тільки для вирішення фіскальних цілей, але й як важливий інструмент фінансового регулювання економіки для виконання невідкладних завдань соціальної політики, підтримки платоспроможного попиту, перерозподілу доходів між різними верствами населення тощо. Зростає значення ефективних управлінських рішень у сфері оподаткування, підвищується відповідальність за їх соціально-економічні наслідки. Поява монографічного дослідження, присвяченого цій темі, є актуальною і своєчасною.

Автором небезпідставно відзначається недостатній рівень правового забезпечення оподаткування: система оподаткування в Україні слабо скерована у напряму стимулювання економічного зростання, не сприяє становленню інноваційно-інвестиційної моделі розвитку, загострює протиріччя між суб'єктами податкових правовідносин, практично не покращує вкрай недосконалої системи адміністрування податків.

Ефективне функціонування інституту податків у сучасній динамічній економіці потребує теоретичного обгрунтування та уточнення змісту й складу, а також взаємозв'язку функцій податків, уточнення термінологічного апарату сучасного оподаткування, зокрема, податкового регулювання як функції загальнодержавного податкового менеджменту. Саме цим зумовлені актуальність та мета монографічного дослідження Пироги I.C.

Важливість розуміння функцій податків полягає в тому, що дозволяє визначити напрям те- оретичного конструювання та практичного використання податкового механізму перерозподілу суспільних доходів. Серед багатьох проблем податкового регулювання, які поставлені й розв'язані в роботі, хочеться звернути увагу лише на функцію податків як регулятора виробництва i споживання. Автор пропонує знижувати ставки податків, якщо на ринку складається еластичність попиту за ціною, а у виробництві є невикористані виробничі потужності. Запропоновано спосіб автоматичної маніпуляції ставками податків, який здійснюється запровадженням еластичної ставки ПДВ, податку на доходи фізичних осіб і ставки єдиного соціального внеску. Еластична ставка податків не має імперативного характеру i $є$ індивідуальною для кожного окремо взятого платника податків. Добровільне використання еластичної ставки податків стимулюватиме детінізацію економіки.

Слід підтримати положення про те, що принциповою особливістю актів податкового законодавства України має бути поєднання імперативних і диспозитивних норм. Критерієм тут має виступати баланс публічного і приватного інтересів.

Також приваблює висновок про необхідність забезпечення оптимального співвідношення між правами і обов'язками суб'єктів податкових правовідносин та запропонований спосіб його реалізації.

У монографії послідовно відстоюється необхідність збереження категорії «механізм правового регулювання», який дозволяє реально використовувати податки через притаманні їм функції для регулювання соціально-економічного розвитку, якщо в суспільстві створена атмосфера поваги до податку, заснована на розумінні як економічної необхідності існування податкової системи, так і встановлених державою правил справляння конкретних податків.

1 Пирога I. С. Механізм податкового стимулювання соціально-економічного розвитку України : монографія. Херсон : Видавничий дім «Гельветика», 2019. 280 с. 
Пропозиції автора достатньо деталізовані. Запропонована авторська редакція окремих статей Податкового кодексу України щодо визначення об'єкта оподаткування, податкової бази, числа і розміру ставок, особливості надання податкових пільг, способів адміністрування податків.

Автор дослідження глибоко розуміє предмет дослідження, ставить і розв'язує важливі проблеми, що торкаються засобів і методів податкового регулювання соціально-економічних процесів. $\mathrm{У}$ роботі вирішено коло взаємопов'язаних завдань, з огляду на які можна стверджувати про досягнення поставленої мети дослідження. Узгодження об'єкта з предметом дослідження, коректне використання автором методів пізнання стало підгрунтям для отримання результатів, які містять наукову новизну та мають практичну цінність. Монографія є певним внеском у розвиток теорії та практики оподаткування. У монографії чітко виставлені цілі, доволі детально окреслені шляхи їх досягнення, запропоновано конкретні зміни до Податкового кодексу України, які дозволяють реалізувати пропозиції автора у правовому полі.

Слід визнати належним методологічний підхід щодо дослідження окреслених проблем. Він свідчить про достатній рівень володіння автором сучасними методами наукового пізнання.
Відзначаючи достатньо високий науковий рівень монографії, хочеться висловити окремі міркування, які б поліпшили, на нашу думку, цінність роботи.

Збільшення прибутків підприємств за рахунок усіх запропонованих автором послаблень податкового тиску не означає, що ці засоби будуть спрямовані на інноваційну діяльність. За радянських часів підприємства мали достатньо ресурсів для впровадження інновацій, але ефективність цієї роботи залишалася низькою.

Висловлене зауваження не знижує загальної високої оцінки проведеного дослідження.

Резюмуючи результати дослідження та беручи до уваги новизну, теоретичне і практичне значення роботи, можна стверджувати, що монографія широко охоплює поставлену проблему і дає її комплексне теоретичне і практичне вирішення, включаючи і формулювання необхідних змін у законодавстві. Монографія I.С. Пироги «Механізм податкового стимулювання соціально-економічного розвитку України», присвячена дослідженням актуальних проблем податкового права, відзначається науковою новизною розв'язання завдань, що мають істотне значення для юридичної науки, і може бути рекомендована до опублікування. 